\title{
Canola is Injured by In-row Nitrogen Placement Associated with Disc Openers, but not by Tine Openers
}

\author{
Pieter A. Swanepoel ${ }^{\mathrm{a}^{*}}$ and Johan Labuschagne $\mathrm{e}^{\mathrm{a}, \mathrm{b}}$
}

a Department of Agronomy, Stellenbosch University, Private Bag X1, Matieland, South Africa, 7600

${ }^{b}$ Western Cape Department of Agriculture, Private Bag X1, Elsenburg, South Africa, 7607

* Corresponding author (email): pieterswanepoel@sun.ac.za

Abbreviations: DAE, days after emergence; LAI, Leaf area index; N, Nitrogen

\begin{abstract}
Seed-drills are used in no-tillage systems to place seed directly in soil. Various furrow-openers exist, each with unique seed and fertilizer placement characteristics, particularly positioning of fertilizer in relation to the position of the seed. Seedling damage may occur if seed and fertilizer placement is not appropriate for the particular crop. Canola (Brassica napus) seed is small, resulting in seedlings susceptible to injury by fertilizers. A study was conducted to evaluate the effect of in-row nitrogen $(\mathrm{N})$ placement with a seed-drill fitted with single and double-chute tine openers, and disc openers. The study was carried out in a Mediterranean-type climate region in South Africa over two years. Plant establishment was reduced by $48 \%$ when canola was established with disc openers with no separation between $\mathrm{N}$ and the seed $(\mathrm{P}<0.05)$. Tine openers were most successful in establishing an acceptable plant population, as well as ensuring high biomass production throughout the season leading to a high leaf area index. Although no yield differences $(\mathrm{P}>0.05)$ were observed between openers, it was concluded that the application of $\mathrm{N}$
\end{abstract}


in the band at the same position as the seed is a risk. Tine openers, either with a single or double seed chute, that separate seed and fertilizer, resulted in the best canola performance.

Keywords: Brassica napus, No-tillage, Planting, Seed-drill, Seed furrow

\section{INTRODUCTION}

No-tillage is a practice widely followed by canola (Brassica napus) producers (Morrison et al. 2016; Swanepoel et al. 2019). This necessitates the use of seed-drills that place seed directly in soil, without prior soil preparation actions. Various seed-drill technologies are available commercially. Seed-drill furrow openers include, inter alia, single or double-chute tine openers and a new generation of seed drills with single or double disc openers. One of the important benefits of disc openers is that discs cause less soil disturbance, often described as being advantageous (Swanepoel et al. 2018).

The development of seed-drill technology and placement of seed directly in the soil has led to the practice of applying all the seed and fertilizer in a single field pass. Different seed-drill openers have been designed with different capabilities of fertilizer placement (Ahmad et al., 2015; Aikins et al., 2018; Swanepoel et al., 2018). With tine openers, fertilizer is placed deeper than the seed, whereas disc openers generally place seed and fertilizer at the same depth. Placement of nitrogen $(\mathrm{N})$ fertilizer in the row has traditionally been recommended for canola produced in regions with Mediterranean-type climates, where soil temperatures are cool during emergence and mineralisation rates slow (Fertasa, 2016). In cool soils, fertilizer placed in the vicinity of the developing seed provides easily accessible nutrients, until roots have been developed to intercept a larger volume of soil for nutrient uptake. Thus, even low rates of $\mathrm{N}$ placed in the row (i.e. $10 \mathrm{~kg} \mathrm{~N} \mathrm{ha}^{-1}$ ) can be beneficial. Damage to seedlings as a result of fertilizer placement is well-recognised and directly affected by the type of opener (Grant et al. 
2002, 2011; Hocking et al. 2003; Johnston et al. 2001, 2002; Pan et al. 2016). Mechanisms of seedling damage include chemical damage through salt or ammonium toxicity, and physical damage through dehydration as a result of an osmotic potential gradient (Pan et al., 2016).

In the Western Cape of South Africa, crop rotation systems are based on bread wheat (Triticum aestivum), but rotated with various crops, including canola. Since the systems are based on wheat, most producers use the same seed-drill to establish both wheat and canola. Because of significantly different fertilizer placement capabilities of different seed-drills openers and interactions with crop seedling physiology, it can be expected that certain crops are more prone to chemical damage (Pan et al., 2016). Because small-seeded crops, like canola, have little seed-reserves to withstand seedling damage during germination, the risk of placing fertilizers close to the seed is particularly high with canola. Furthermore, seedling health of single radicle or tap rooted crops, such as canola, is more prone to injury from fertilizer than wheat with a fibrous root system. Yet the impact of seed-drill openers on canola is not well understood. Different planting and fertilization strategies are necessary for canola and wheat production. A previous study on canola establishment with different furrow openers mounted on a seed-drill in the Western Cape reported that disc openers resulted in a lower yield (Swanepoel et al., 2019). However, mechanisms of reduced productivity could only be ascribed to multiple reasons, including hairpinning (pushing residue into the furrow without cutting through residue), crop residue handling and chemical or physical injury from fertilizers, and more research is warranted. The aim of this study was to evaluate the effect of in-row N placement with a seeddrill fitted with single and double-chute tine openers, and disc openers. 


\section{MATERIALS AND METHODS}

\section{Study site}

The trial was conducted over two production seasons (2017 and 2018) at Langgewens Research Farm (33 16’42.33” S; 18 42’11.62” E; 191 m above sea level) near Moorreesburg, South Africa. This region has a Mediterranean-type climate, with approximately $80 \%$ of the rainfall between April and September. In 2017, the rainfall during the growing season was $180 \mathrm{~mm}$, which is $55 \%$ lower than the long-term average growing season rainfall of $328 \mathrm{~mm}$ (Fig. 1). In 2018, the growing season rainfall was $341 \mathrm{~mm}$, similar to the long-term average.

Soils types were variable within the site, mostly duplex of nature, which is a typical characteristic of the region. According to the South African classification system, the most common soil forms are Glenrosa and Swartland soil forms (Soil Classification Working Group 1991). According to the USDA soil taxonomy and the International Classification Systems these soils are classified as peducutanic-lithic and glossic (IUSS Working Group WRB, 2006; Soil Survey Staff, 2003). Soil fertility attributes were within the acceptable range for canola production (Table 1), and corresponded to the typical situation in the region (Swanepoel and Tshuma 2017). Soils had a sandy-loam texture.

\section{Experimental Design and Treatments}

The trial was located within fields that have been in a crop rotation system managed under notillage for more than 10 years. The preceding crop was wheat. Four treatments were laid out in a randomised block design replicated eight times across various soil forms. Plot dimensions were $1.5 \mathrm{~m}$ x $20 \mathrm{~m}$. Replication across various soil forms was done to ensure representativeness in true situations on farms, as the soils are highly variable within short distances in the region. However, previous research has shown that a combination of various soil physical, chemical and biological 
indicators of soil quality did not influence performance of openers in the region (Swanepoel et al., 2019).

Treatments included establishment of canola by three different openers and a control. Tine openers placed fertilizer a few centimetres deeper than a single row of seed along the same vertical axis (Fig. 2). Single-chute tine openers placed seed in the middle of the V-shaped furrow created by the opener, whereas double-chute tine openers placed seed in the sidewalls on both sides of the furrow, with fertilizer in the middle of the furrow, a few centimetres deeper. Seed of the single and double-chute tine openers were placed between 9 and $11 \mathrm{~mm}$ deep (Fig. 3). A disc opener did not split seed and fertilizer and both were placed in the middle of the furrow, only approximately $10 \mathrm{~mm}$ beneath the soil surface. A control involved establishment of canola with a disc opener, but without any fertilizer placed in the row; the same amount of fertilizer that was placed in the row with the other treatments was broadcast on the soil surface directly after planting.

\section{Planting and Management of Canola}

Canola was planted on the $3^{\text {rd }}$ of May in both 2017 and 2018. In both years, the soil was fairly dry (gravimetric soil water content $<8 \%$ ) at the time of planting. Canola was established at a seeding rate of $3.5 \mathrm{~kg} \mathrm{ha}^{-1}\left(>4 \mathrm{~g} 1000 \mathrm{seeds}^{-1}\right)$, which approximates to 88 seeds $\mathrm{m}^{-2}$. Row spacing for all openers was $300 \mathrm{~mm}$. Row spacing for canola typically range between 175 and $300 \mathrm{~mm}$ in the region. The cultivar Atomic was used, which is an atrazine-tolerant cultivar, found to perform well in previous cultivar evaluation trials on Langgewens Research Farm.

Fertilisation programmes used in the region are based on guidelines that were locally developed (Fertasa, 2016). For all nutrients the fertilizer rate is based on soil analyses, except for N. Nitrogen fertilization programmes are based on target yield (determined by in-season 
rainfall), soil texture and preceding crop. At planting, urea was used as an $\mathrm{N}$ source applied at a rate of $10 \mathrm{~kg} \mathrm{~N} \mathrm{ha}^{-1}$, a rate often used for canola in the region. Soil tests indicated that some $\mathrm{P}$ and no $\mathrm{K}$ were needed. Thus, $6 \mathrm{~kg} \mathrm{P} \mathrm{ha}{ }^{-1}$, in the form of double super phosphate, was placed in the row to all treatments at planting. Additional fertilizer requirement was based on soil test results was broadcast in two increments, according to the fertilizer programme and best practice in the region. At 20 days after establishment, $40 \mathrm{~kg} \mathrm{~N} \mathrm{ha}^{-1}, 5 \mathrm{~kg} \mathrm{~K} \mathrm{ha}^{-1}$ and $8 \mathrm{~kg} \mathrm{~S} \mathrm{ha}^{-1}$ fertilizer was broadcast. An additional $30 \mathrm{~kg} \mathrm{~N} \mathrm{ha}^{-1}$ was broadcast 60 days after establishment. Boron was applied as a foliar spray prior to flowering in both years. Weed and pest control were managed with pesticides according to recommended best practice for the region. No serious weed or pest issues occurred during either 2017 or 2018.

An Equalizer no-till seed-drill with interchangeable openers was used [Equalizer AG (Pty) Ltd., Cape Town, South Africa]. This avoided any bias resulting from differences in weight and seed delivery efficiency between different openers. Each opener unit had a trip function which was independent from the other openers, which prevented all openers lifting above the soil surface when the planter ran over a large rock. The tractor planted at a speed of $5 \mathrm{~km} \mathrm{~h}^{-1}$.

\section{Data Collection}

Plant population was determined 30 days after emergence by counting the number of seedlings in five $1 \mathrm{~m}$ rows per plot. At 60 and 90 days after emergence as well as when the plants reached physiological maturity, ten plants per plot were sampled by cutting at ground level. Leaves were separated from the rest of the plant and scanned with a leaf area apparatus (LI-3100 Area Meter, LI-Cor Inc. Lincoln, Nebraska USA) and the leaf area index (LAI) was subsequently determined. The leaves and remaining plant parts were again combined and dried at $60^{\circ} \mathrm{C}$ for 72 hours and weighed to determine aboveground biomass production. Canola was harvested on 1 November 
2017 and 22 October 2018 with a HEGE 140 plot combine. Subsequently, yield was determined by weighing the seed of each plot. Thousand seed mass and oil content was determined with an Inframatic 9500 NIR Grain Analyzer (Perten Instruments 2019, PerkinElmer Inc.).

\section{Statistical Analyses}

Linear mixed models were used to investigate the effects of openers and associated $\mathrm{N}$ placement. Data that did not follow a normal distribution were log transformed to fit the model assumption. Back-transformed data is presented. The fixed effects were treatment (opener and associated $\mathrm{N}$ placement), year and interactions amongst the treatments and year. Block was a random effect. Models were calculated in the VEPAC package using restricted maximum likelihood with pvalues for the significance of each variable, at a 95\% confidence level, calculated using type III analysis of variance (Goodnight, 1980). A Bonferroni post-hoc test was performed to obtain the between-contrast coefficients, contrast estimates, and the univariate test of significance for planned comparisons. Data analysis was undertaken with Statistica version 13 (TIBCO Software Inc., 2018).

\section{RESULTS}

Plant population was significantly affected $(\mathrm{P}<0.05)$ by opener type and the associated $\mathrm{N}$ placement characteristics, but was not affected by year (Table 2). Plant population of the canola planted with single- and double-chute tine openers were highest $(\mathrm{P}<0.05)$, and did not differ $(\mathrm{P}>0.05)$ from the control treatment. Double-chute tine openers established 68 plants $\mathrm{m}^{-2}$ and single chute tine openers, 72 plants $\mathrm{m}^{-2}$ (Fig. 4). Plant establishment was reduced by $48 \%$ in both years when canola was established with disc openers compared with a single-chute tine opener $(\mathrm{P}<0.05)$. The control resulted in a reduction in plant establishment of $26 \%$ compared to single- 
chute tine openers. Nitrogen placement therefore explains some, but not all of the variation caused by the different openers.

Aboveground biomass production and LAI was significantly affected by treatments at 60 and 90 days after establishment, but effects on biomass production were no longer visible at physiological maturity (Table 2). A similar response pattern for biomass production at 60 days after emergence than that of plant population was observed, i.e. single-chute tine openers resulted in the highest $(\mathrm{P}<0.05)$ biomass production, but did not differ from that of the doublechute tine opener, and the disc opener had the lowest $(\mathrm{P}<0.05)$ biomass production (Fig. 5). At 90 days after emergence, a significant interaction between treatment and year, for both biomass production and LAI means that the same responses cannot be expected through years (Fig. 5 and 6). The control, double-chute and standard single-chute tine openers resulted in the highest biomass production at 90 days after emergence in 2018. The disc openers resulted in a lower $(\mathrm{p}<0.05)$ biomass production in 2018 . However, in 2017 , treatment response was similar $(\mathrm{p}>0.05)$ for both biomass production and LAI at 90 days after emergence. By physiological maturity, there is only some evidence $(\mathrm{p}<0.1)$ that the disc opener and associated $\mathrm{N}$ placement characteristics did result in an inferior biomass production (Table 2). Year also had a significant influence on biomass production and LAI, but this could be directly related to rainfall amount and distribution (Fig. 3). In 2017, biomass production from 90 days after emergence to physiological maturity, was lower $(\mathrm{P}<0.05)$ compared to that of 2018 as a result of the very low rainfall in 2017 .

Crop yield was not affected by treatments, but was higher $(\mathrm{P}<0.05)$ in 2018 than in 2017 (Table 2). In 2017 the crop yield was $769.0 \pm 304.0 \mathrm{~kg} \mathrm{ha}^{-1}$ and in 2018: $1335.7 \pm 420.1 \mathrm{~kg} \mathrm{ha}^{-1}$ (Fig. 5). Because of a very low crop yield in 2017 as result of droughts, seed quality data is not 
presented for 2017 (Table 2). For 2018, the thousand seed mass of the double-chute tine opener was the highest $(\mathrm{P}<0.05)$ (Table 3). The control, single-chute tine and disc opener had a similar thousand seed mass. Oil content ranged from 43.2 to $43.8 \%$, but no significant differences between treatments were recorded (Table 2; data not shown).

With the control, seed was established with a disc opener, but nitrogen was broadcast rather than placed in the row. If bars do not share a common letter, the bars were significantly different $(\mathrm{P}<0.05)$.

\section{DISCUSSION}

It is clear that tine openers that had the ability to separate fertilizer from seed in the row, had the lowest risk of seedling injury. An optimal target canola plant population of more than 40 plants $\mathrm{m}^{-2}$ have been reported for the region (Swanepoel et al., 2019), although no economic impact for plant populations as low as 25 plants $\mathrm{m}^{-2}$ have been reported elsewhere (French et al., 2016). Planting canola with $10 \mathrm{~kg} \mathrm{~N} \mathrm{ha}^{-1}$ with a disc opener that does not have the ability to separate seed from fertilizer, has resulted in suboptimal plant populations of less than 40 plants $\mathrm{m}^{-2}$. The effect of a low plant population was visible throughout the season expressed as a low biomass productivity and a low LAI. However, canola in both years compensated by branching and increased pod formation, thereby producing more seed per plant for treatments that resulted in low plant populations, and no effect on crop yield is reported. The ability of canola to compensate in yield has also been reported by Hocking et al. (2003) and Johnston et al. (2001). However, in years with favorable climate conditions, pod number will not be able to fully compensate for yield (Angadi et al., 2003) and suboptimal plant populations $\left(<40\right.$ plants $\left.\mathrm{m}^{-2}\right)$ are not ideal. 
In contrast to the current study, Thavarajah et al. (2003) found that position of $\mathrm{N}$ in relation to the seed (urea side-wall or mid-row placement) had no significant influence on plant population, but high rates of urea-N resulted in seedling damage. Canola seed is relatively expensive in South Africa, and producers tend to plant at lower seeding rates to save on seed costs. However, seeding at low densities is not advised, since this may lead to the risk of reducing potential crop yield if plant populations and LAI are low. Furthermore, weeds proliferate in fields with a low plant population as competition for resources, particularly light, favours weed growth (French et al., 2016). Because weed control, in particular ryegrass (Lolium rigidum) in the region is particularly constraining yield (French et al., 2016; MacLaren et al. 2019), low canola plant populations are not optimal. In the current trials, weeds were controlled effectively.

During planting, the seeds were placed at approximately the same depth for all the openers, so differences cannot be ascribed to different seed placement characteristics. Nitrogen placement characteristics with a disc opener partially explains reduced performance of establishment of canola when planted with a disc opener. However, the control treatment resulted in intermediate plant performance between the disc and tine treatments. Other reasons for canola to perform better with a tine opener might include soil disturbance that affect seed-to-soil contact, residue load on the row and seedbed quality (Grant et al., 2002; Swanepoel et al., 2018; Swanepoel et al., 2019). However, performance of seed-furrow openers seem to be crop specific. Swanepoel et al. (2018) reported that disc openers are the superior option when establishing wheat in poor quality and dry soils. However, seedling injury with increased $\mathrm{N}$ rates in the seed furrow has also been reported for wheat and barley (Hordeum vulgare) (Karamanos et al., 2008). 
Canola is usually produced in crop rotation systems rather than in monoculture systems, and decision on the best opener type should not be made purely on performance of canola, but rather multiple crops used in the system. For instance, it was shown by Swanepoel et al. (2018) that wheat produced in crop rotation systems in the Western Cape are not sensitive to opener-type. Wheat performed well when planted with disc openers, although no differences were reported between disc and tine openers when soil quality was high (Swanepoel et al., 2018). Other advantages to consider for choosing disc openers include low soil disturbance (MacLaren et al., 2019), uniform plant emergence (Chen et al., 2004) and better handling of crop residue (Swanepoel et al., 2019). More research is also recommended to understand the economics of the using different openers, since the operating and maintenance costs of seed-drills with different openers may vary.

No treatment effect on crop yield or quality was reported in this study, even though seed quality data was based on a single year. Grant et al. (2011) found that application of side-banded $\mathrm{N}$ fertilizer $2.5 \mathrm{~cm}$ away and $2.5 \mathrm{~cm}$ below the seed increased seed protein content and decreased oil concentration, but Hocking et al. (2003) reported no effect on seed quality. Response of canola crop yield and quality is site specific and sensitive to tillage system and seedbed conditions (Grant et al., 2002). Even though seed protein content was not measured in the current study, protein content and oil content usually have a strong inverse relationship (Pritchard et al., 2000). No treatment response to protein content is expected because there were no treatment response $(\mathrm{P}>0.05)$ to oil content observed. Currently South African farmers are not incentivised for increased oil or protein content of canola seed.

The position and depth of $\mathrm{N}$ placement, as well as $\mathrm{N}$ source, can influence the flux of plant available $\mathrm{N}$ in the soil, and hence affect availability of $\mathrm{N}$ supply to the seedling. Although $\mathrm{N}$ 
supply to the seedling is highlighted as there are benefits to placing $\mathrm{N}$ in vicinity to of the seed (Thavarajah et al., 2003), mixing canola seed and fertilizer in the row, as is the case with disc openers, is not advised. Johnston et al., (2002) tested fertilizer placement options for winter-type canola planted prior to soil freeze-up (dormant seed) or in the early spring in Canada. Although seeding techniques and crop phenology is significantly different in Canada, placement of $\mathrm{N}$ in the row also resulted in variable yield and seed quality responses. The findings of Johnston et al. (2002) therefore supports the premise that placing $\mathrm{N}$ in vicinity of the seed should be avoided.

\section{CONCLUSION}

Although the results of this study may differ between sites and over years, the application of $\mathrm{N}$ in the band at the same position as the seed is, a risk, even at a low $\mathrm{N}$ rate of $10 \mathrm{~kg} \mathrm{ha}^{-1}$. Given the importance of crop establishment to achieving high canola crop yields and ensuring economic success, single or double-chute tine openers that separate seed and fertilizer provided good crop establishment and should be recommended to producers. The risk of reduced yields is higher with low plant populations in favorable years, and with a high input crop such as canola, a financial risk is incurred if the plant population dips below 40 plants $\mathrm{m}^{-2}$ to maintain yield. Given the reduced plant population (lower than 40 plants $\mathrm{m}^{-2}$ ) of canola following placement of $\mathrm{N}$ with disc openers, it is recommend that this practice should be avoided. For disc openers, separating seed and fertilizer through broadcasting the fertilizer prior to seeding canola can increase seedling establishment, even though it does not fully negate the reduction in plant population compared to using tine openers. Tine openers, either with a single- or double-chute, that separate seed and fertilizer, resulted in the highest canola establishment, biomass production and thousand seed weight. 


\section{ACKNOWLEDGMENTS}

This work was supported by the Protein Research Foundation (Project no.: P07/28/217). The

Western Cape Department of Agriculture is acknowledged for allowing us to work on

Langgewens Research Farm. We wish to thank Mr Martin la Grange and his technical team who

established the trial as well as Mr Heinrich van Zyl for managing the trial. Mr S. Silwana is also

acknowledged for collecting some of the data as part of in his MSc thesis. The late Prof André

Agenbag and Dr Johann Strauss is thanked for their involvement in the project. Theebo Tech

(Pty) Ltd donated the Equalizer seeding equipment with interchangeable seed-furrow openers.

\section{REFERENCES}

Ahmad, F., D. Weimin, D. Qishuo, M. Hussain, and K. Jabran. 2015. Forces and straw cutting performance of double disc furrow opener in no-till paddy soil. Plos one. 10:e0119648, https://doi.org/10.1371/journal.pone.0119648

Aikins, K.A., D.L. Antille, T.A. Jensen, J.B. Barr, M. Ucgul, and J.M. Desbiolles. 2018. Notillage tine furrow opener performance: soil-tool-residue interactions, tool geometry and settings. In 2018 ASABE Annual International Meeting. Am. Soc. Agric. Biol. Eng. p. 1. doi:10.13031/aim.201800251

Angadi, S.V., H.W. Cutforth, B.G. McConkey, and Y. Gan. 2003. Yield adjustment by canola grown at different plant populations under semiarid conditions. Crop Sci. 43(4):1358-1366. doi:10.2135/cropsci2003.1358

Chen, Y., S. Tessier, and B. Irvine. 2004. Drill and crop performances as affected by different drill configurations for no-till seeding. Soil Tillage Res. 77:147-155. https://doi.org/10.1016/j.still.2003.12.001

Fertasa (Fertilizer Association of Southern Africa). 2016. Fertilizer Handbook. 8th Revised Edition, Pretoria, South Africa.

French, R.J., M. Seymour, and R.S. Malik. 2016. Plant density response and optimum crop densities for canola (Brassica napus L.) in Western Australia. Crop Pasture Sci. 67:397-408. doi:10.1071/CP15373

Goodnight, J.H. 1980. Tests of hypotheses in fixed effects linear models. Communications in Statistics, A9:167-180. doi:10.2134/agronj2016.02.0122.

Grant, C.A., D.A. Derksen, D.L. McLaren, and R.B. Irvine. 2011. Nitrogen fertilizer and urease inhibitor effects on canola seed quality in a one-pass seeding and fertilizing system. Field Crop. Res. 121:201-208. https://doi.org/10.1016/j.fcr.2010.10.012 
Grant, C.A., K.R. Brown, G.J. Racz, and L.D. Bailey. 2002. Influence of source, timing and placement of nitrogen fertilization on seed yield and nitrogen accumulation in the seed of canola under reduced- and conventional-tillage management. Can. J. Plant Sci. 82:629-638

Hocking, P.J., J.A. Mead, A.J. Good, and S.M. Diffey. 2003. The response of canola (Brassica napus L.) to tillage and fertilizer placement in contrasting environments in southern NSW. Aust. J. Exp. Agric. 43:1323-1335. https://doi.org/10.1071/EA02233

IUSS Working Group. 2006. WRB, World reference base for soil resources. 2nd ed. World Soil Resources Rep. 103. FAO, Rome

Johnston, A.M., E.N. Johnson, K.J. Kirkland, and F.C. Stevenson. 2002. Nitrogen fertilizer placement for fall and spring seeded Brassica napus canola. Can. J. Plant Sci. 82:15-20, https://doi.org/10.4141/P01-038

Johnston, A.M., G.P. Lafond, G.E. Hultgreen, and G.L. Hnatowich. 2001. Spring wheat and canola response to nitrogen placement with no-till side band openers. Can. J. Plant Sci. 8:191-198. https://doi.org/10.4141/P00-070

Karamanos, R.E., J.T. Harapiak, and N.A. Flore. 2008. Revisiting seedrow nitrogen placement with wheat and barley. Can. J. Plant Sci. 88 1073-1086. doi:10.4141/CJPS08085

MacLaren, C., J. Storkey, J.A. Strauss, P.A. Swanepoel, and K. Dehnen-Schmutz. 2019. Livestock in diverse cropping systems improve weed management and sustain yields whilst reducing inputs. J. Appl. Ecol. 56:144-156. https://doi.org/10.1111/1365-2664.13239

Morrison, M.J., K.N. Harker, R.E. Blackshaw, C.J. Holzapfel, and J.T. O’Donovan. 2016. Canola yield improvement on the Canadian Prairies from 2000 to 2013. Crop Pasture Sci. 67:245-252, https://doi.org/10.1071/CP15348

Pan, W.L., I.J. Madsen, R.P. Bolton, L. Graves, and T. Sistrunk. 2016. Ammonia/ammonium toxicity root symptoms induced by inorganic and organic fertilizers and placement. Agron. J. 108:2485-2492. doi:10.2134/agronj2016.02.0122

Pritchard, F.M., H.A. Eagles, R.M. Norton, P.A. Salisbury, and M. Nicolas. 2000. Environmental effects on seed composition of Victorian canola. Aust. J. Exp. Agric. 40:679-685, https://doi.org/10.1071/EA99146

Soil Classification Working Group. 1991. Soil classification: A taxonomic system for South Africa: Memoirs on the agricultural natural resources of South Africa No. 15. Dep. of Agric. Development, Pretoria, South Africa

Soil Survey Staff. 2003. Keys to soil taxonomy. USDA, Washington, DC.

Swanepoel, P.A., and F. Tshuma. 2017. Soil quality effects on regeneration of annual Medicago pastures in the Swartland of South Africa. Afr. J. Range Forage Sci. 34:201-208.

Swanepoel, P.A., G.A. Agenbag, and J.A. Strauss. 2018. Considering soil quality when comparing disc and tine seed-drill openers for establishing wheat. S.A. J. Plant Soil. 35:317320, https://doi.org/10.1080/02571862.2017.1374478

Swanepoel, P.A., P.J.G. le Roux, G.A. Agenbag, J.A. Strauss, and C. MacLaren. 2019. Seed-drill opener type and crop residue load affect canola establishment, but only residue load affects yield. Agron. J. 111:1-8. doi:10.2134/agronj2018.10.0695 
Thavarajah, D., J.J. Schoenau J.R. Bettany G. Hultgreen, P. Qian, S.S. Malhi, and R. Lemke. 2003. Early Supplies of Available Nitrogen to Seed-Row of a Canola Crop as Affected by Fertilizer Placement, J. Plant Nutr. 26: 683-690, DOI: 10.1081/PLN-120017675.

TIBCO Software. 2018. Statistica (data analysis software system), version 13. TIBCO Softw., Palo Alto, CA.

\section{List of Figures}

Fig. 1: Monthly rainfall on Langgewens Research Farm (South Africa) for 2017 and 2018, compared to the 30-year long-term average monthly rainfall

Fig. 2: The tine seeder unit (left) that places fertilizer deeper than the seed. Different tine openers can be fitted to the seeder unit. Standard single chute tine openers (bottom right) place seed directly in the middle of the furrow, where double-chute tine openers (top right) band place seed in the sidewalls of the furrow. Figure supplied Equalizer AG (Pty) Ltd., Cape Town, South Africa

Fig. 3: A seeder unit fitted with a disc opener that does not split seed and fertilizer and both were placed in the middle of the furrow. Figure supplied Equalizer AG (Pty) Ltd., Cape Town, South Africa

Fig. 4: Plant populations following establishment with a single disc opener, single- and doublechute tine opener, with its associated $\mathrm{N}$ placement characteristics. The treatment $\mathrm{x}$ year interaction was not significant $(\mathrm{P}>0.05)$, therefore main effects are shown. With the control, seed was established with a disc opener, but $\mathrm{N}$ was broadcast rather than placed in the row. If bars do not share a common letter, the bars were significantly different $(\mathrm{P}<0.05)$.

Fig. 5. Aboveground biomass and crop yield of canola planted with a single disc opener, singlechute (SC) and a double-chute (DC) tine opener, with its associated $\mathrm{N}$ placement 
characteristics. With the control, seed was established with a disc opener, but nitrogen was broadcast rather than placed in the row. If bars do not share a common letter, the bars were significantly different $(\mathrm{P}<0.05)$.

Fig. 6. Leaf area index (LAI) of canola planted with a single disc opener, single-chute (SC) and double-chute (DC) tine opener, with its associated N placement characteristics. With the control, seed was established with a disc opener, but nitrogen was broadcasted rather than placed in the row. If bars do not share a common letter, the bars was significantly different $(\mathrm{P}<0.05)$

\section{Tables}

Table 1: Soil fertility attributes $( \pm$ standard deviation) for samples $(n=9)$ collected to a depth of $150 \mathrm{~mm}$ from thre trial site on Langgewens Research Farm, South Africa

\begin{tabular}{lll}
\hline Soil fertility attribute & 2017 & 2018 \\
\hline $\mathrm{pH}(\mathrm{KCl})$ & $5.79 \pm 0.17$ & $5.23 \pm 0.28$ \\
Electrical resistance $(\mathrm{Ohm})$ & $444.7 \pm 209.0$ & $516.7 \pm 101.1$ \\
Exchangeable acidity $\left(\mathrm{cmol} \mathrm{kg}^{-1}\right)$ & $0.00 \pm 0.00$ & $0.66 \pm 0.14$ \\
Exchangeable Ca $\left(\mathrm{mg} \mathrm{kg}^{-1}\right)$ & $1408.0 \pm 281.9$ & $959.3 \pm 162.0$ \\
Exchangeable $\mathrm{Mg}\left(\mathrm{mg} \mathrm{kg}^{-1}\right)$ & $215.0 \pm 76.5$ & $179.5 \pm 38.0$ \\
Exchangeable K $\left(\mathrm{mg} \mathrm{kg}^{-1}\right)$ & $163.4 \pm 24.9$ & $174.0 \pm 36.9$ \\
Exchangeable $\mathrm{Na}\left(\mathrm{mg} \mathrm{kg}^{-1}\right)$ & $57.0 \pm 42.8$ & $31.3 \pm 13.2$ \\
Cation exchange capacity $\left(\mathrm{cmol} \mathrm{kg}^{-1}\right)$ & $9.48 \pm 1.49$ & $7.29 \pm 0.66$ \\
Extractable P $\left(\mathrm{mg} \mathrm{kg}^{-1}\right)$ & $93.33 \pm 15.47$ & $63.00 \pm 5.16$ \\
Extractable S $\left(\mathrm{mg} \mathrm{kg}^{-1}\right)$ & $31.20 \pm 23.16$ & $20.50 \pm 5.50$ \\
$\mathrm{Cu}\left(\mathrm{mg} \mathrm{kg}^{-1}\right)$ & $1.35 \pm 0.40$ & $1.86 \pm 0.17$ \\
Mn $\left(\mathrm{mg} \mathrm{kg}^{-1}\right)$ & $141.3 \pm 53.3$ & $158.0 \pm 62.5$ \\
Zn $\left(\mathrm{mg} \mathrm{kg}^{-1}\right)$ & $3.35 \pm 1.18$ & $2.93 \pm 0.09$ \\
B (mg kg-1) & $0.34 \pm 0.10$ & $0.41 \pm 0.03$ \\
Organic C $(\%)$ & $0.83 \pm 0.38$ & $1.14 \pm 0.19$ \\
\hline
\end{tabular}


Table 2. ANOVA F statistics and P-values for the mixed models of agronomic parameters of canola to opener type and its associated nitrogen placement characteristics in the row, and year (where applicable). Block was included as a random variable in each model. Bold values are used to illustrate $\mathrm{P}$-values $<0.05 . \mathrm{DAE}=$ days after emergence

\begin{tabular}{|c|c|c|}
\hline Variable & F-statistic & p-value \\
\hline \multicolumn{3}{|l|}{ Plant population } \\
\hline Year & 0.361 & 0.567 \\
\hline Treatment & 22.024 & $<0.001$ \\
\hline Treatment:Year & 1.056 & 0.378 \\
\hline \multicolumn{3}{|l|}{ Biomass (60 DAE) } \\
\hline Year & 6.477 & 0.038 \\
\hline Treatment & 10.566 & $<0.001$ \\
\hline Treatment:Year & 1.539 & 0.219 \\
\hline \multicolumn{3}{|l|}{ Biomass (90 DAE) } \\
\hline Year & 97.150 & $<0.001$ \\
\hline Treatment & 6.780 & $<0.001$ \\
\hline Treatment:Year & 3.538 & 0.023 \\
\hline \multicolumn{3}{|c|}{ Biomass (physiological maturity) } \\
\hline Year & 42.405 & $<0.001$ \\
\hline Treatment & 2.573 & 0.067 \\
\hline Treatment:Year & 1.783 & 0.166 \\
\hline \multicolumn{3}{|l|}{ Leaf area index (60 DAE) } \\
\hline Year & 25.829 & 0.001 \\
\hline Treatment & 2.936 & 0.045 \\
\hline Treatment:Year & 1.156 & 0.338 \\
\hline \multicolumn{3}{|l|}{ Leaf area index (90 DAE) } \\
\hline Year & 26.321 & 0.001 \\
\hline Treatment & 1.927 & 0.141 \\
\hline Treatment:Year & 3.255 & 0.031 \\
\hline \multicolumn{3}{|l|}{ Crop yield } \\
\hline Year & 11.959 & 0.011 \\
\hline Treatment & 0.138 & 0.937 \\
\hline Treatment:Year & 0.939 & 0.430 \\
\hline \multicolumn{3}{|l|}{ Thousand seed mass } \\
\hline Treatment & 5.260 & 0.007 \\
\hline \multicolumn{3}{|l|}{ Oil content } \\
\hline Treatment & 0.669 & 0.580 \\
\hline
\end{tabular}


Table 3. Thousand seed mass of canola planted with a single disc opener, single and doublechute tine openers, with its associated $\mathrm{N}$ placement characteristics. With the control, seed was established with a disc opener, but nitrogen was broadcasted rather than placed in the row. Superscript letters denote significant differences $(\mathrm{P}<0.05)$.

\begin{tabular}{ll}
\hline Opener & Thousand seed weight \\
\hline Control & $3.22 \pm 0.072^{\mathrm{b}}$ \\
Disc & $3.13 \pm 0.076^{\mathrm{b}}$ \\
Double-chute tine & $3.41 \pm 0.129^{\mathrm{a}}$ \\
Single-chute tine & $3.21 \pm 0.097^{\mathrm{b}}$ \\
\hline
\end{tabular}




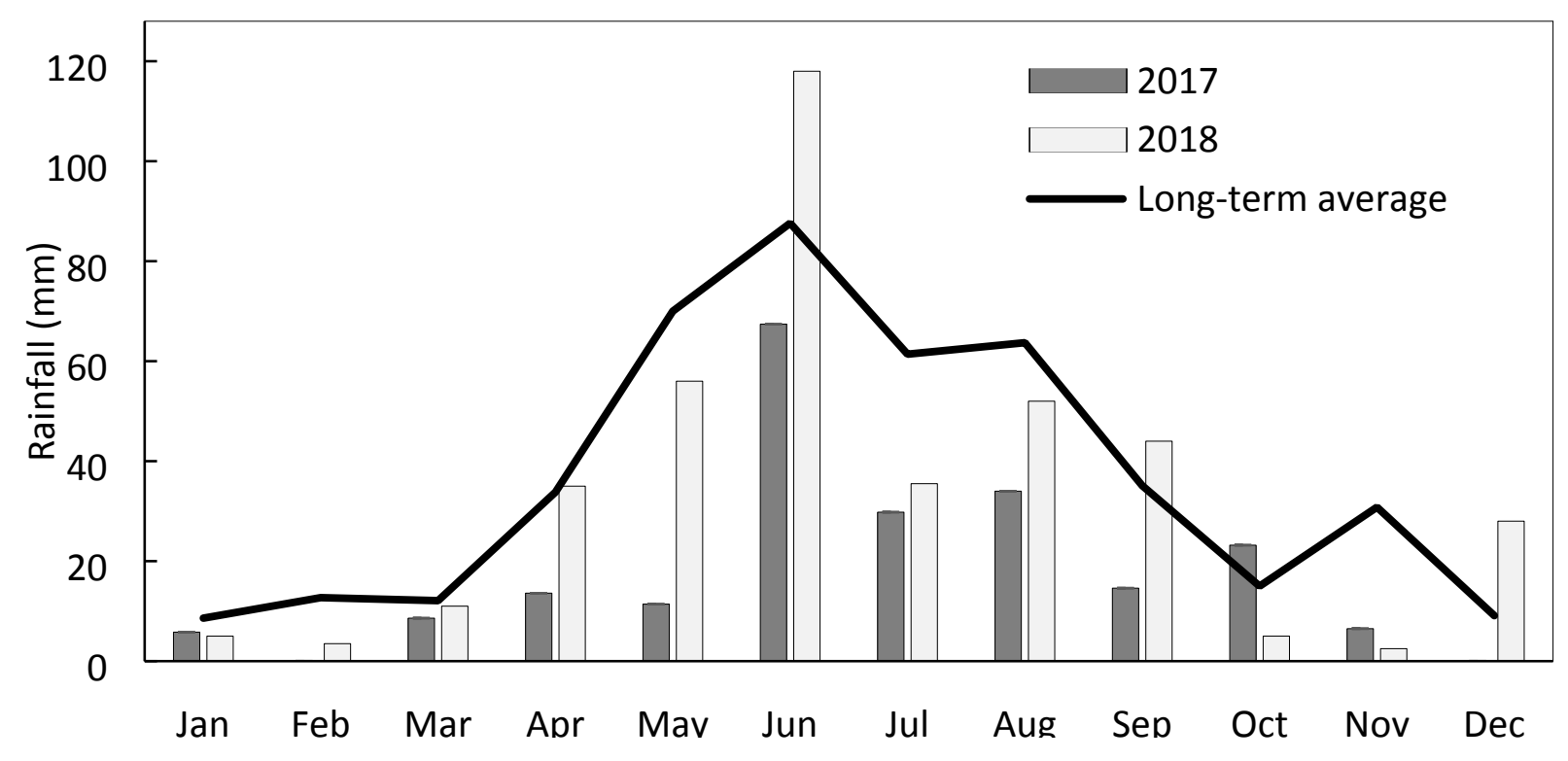

Fig. 1. Monthly rainfall on Langgewens Research Farm (South Africa) for 2017 and 2018, compared to the 30-year long-term average monthly rainfall 

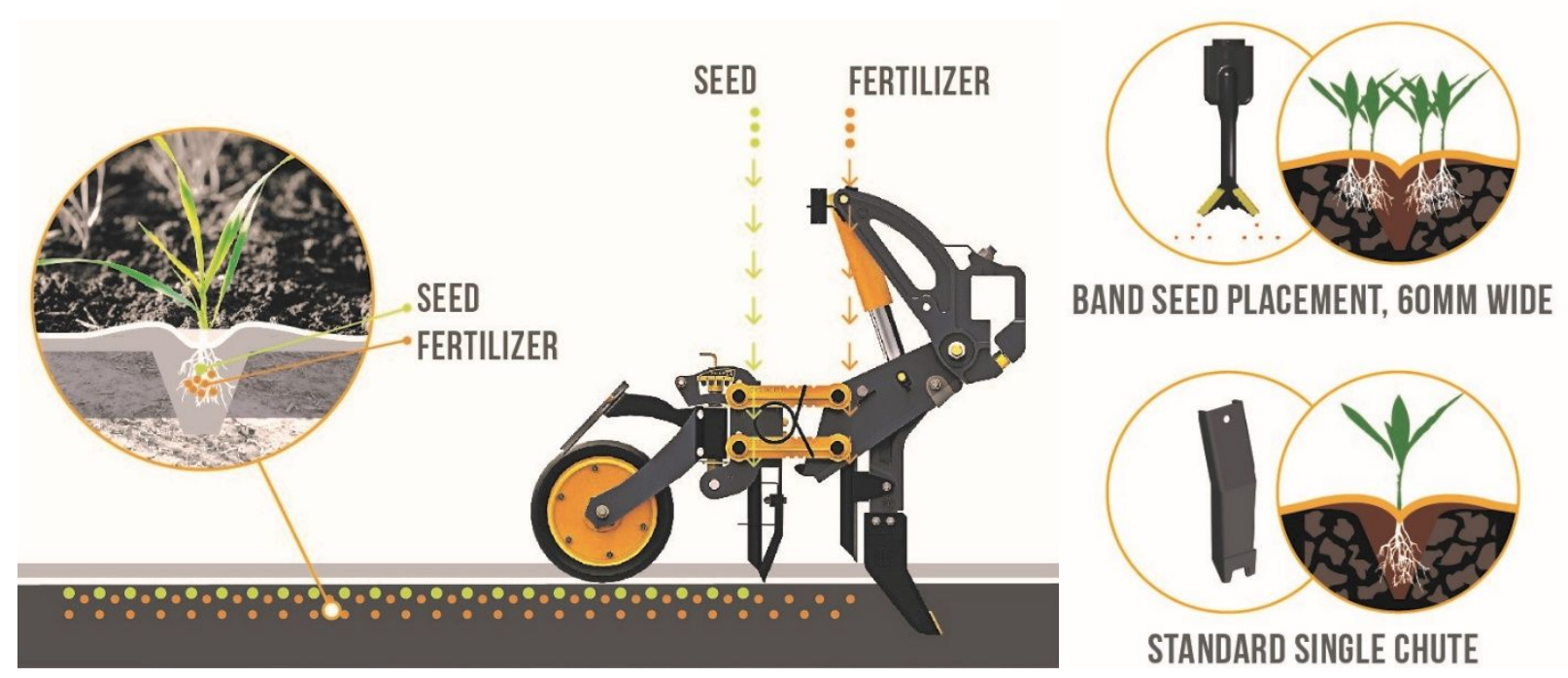

Fig. 2: The tine seeder unit (left) that places fertilizer deeper than the seed. Different tine openers can be fitted to the seeder unit. Standard single chute tine openers (bottom right) place seed directly in the middle of the furrow, where double-chute tine openers (top right) band place seed in the sidewalls of the furrow. Figure supplied Equalizer AG (Pty) Ltd., Cape Town, South Africa 


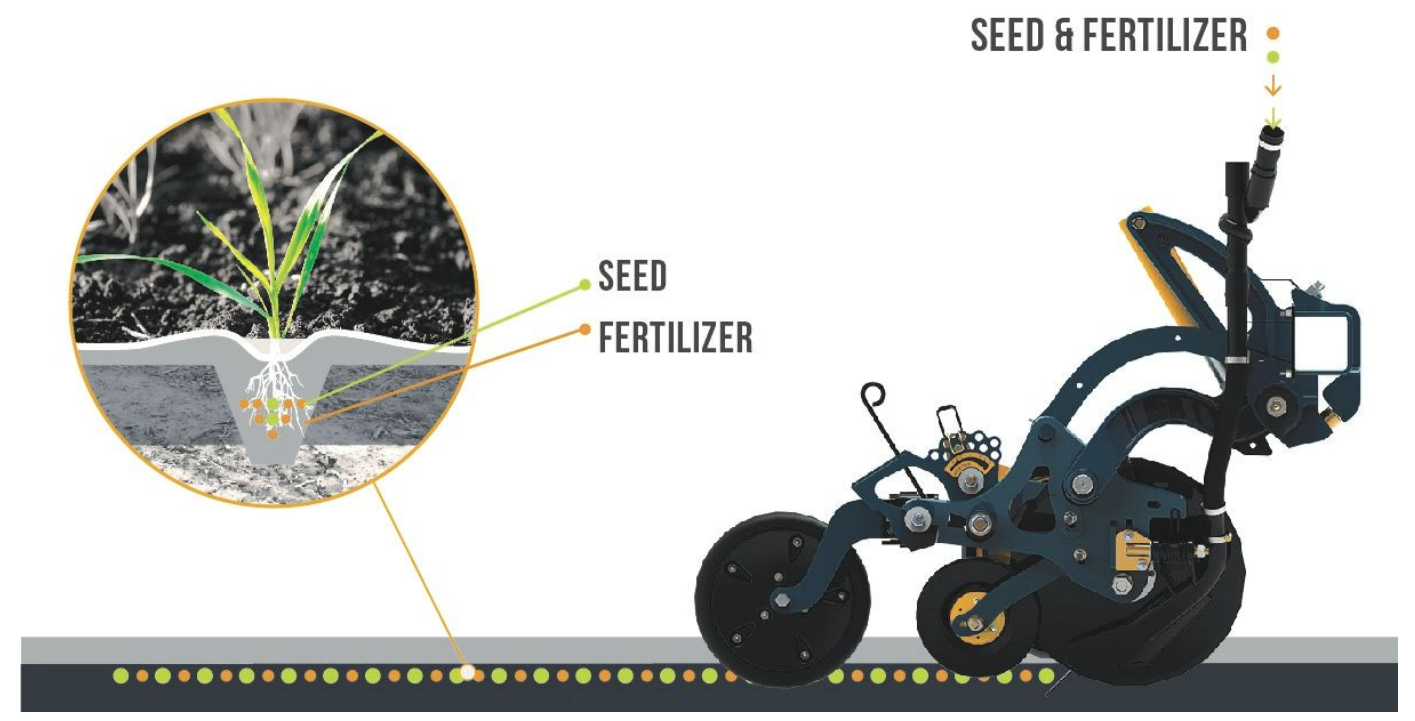

Fig. 3: A seeder unit fitted with a disc opener that does not split seed and fertilizer and both were placed in the middle of the furrow. Figure supplied Equalizer AG (Pty) Ltd., Cape Town, South Africa 


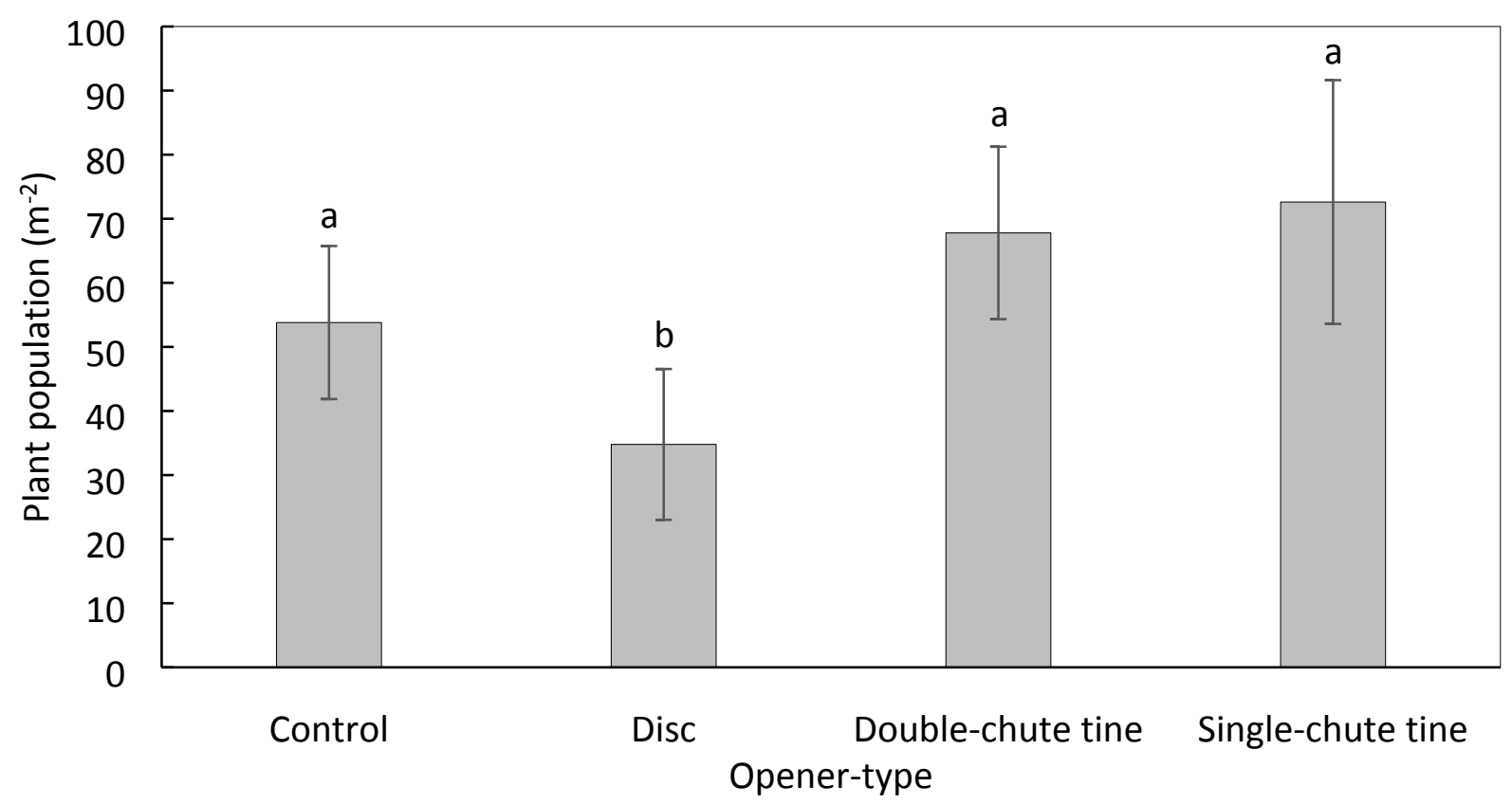

Fig. 4. Plant populations following establishment with a single disc opener, single- and doublechute tine opener, with its associated $\mathrm{N}$ placement characteristics. The treatment $\mathrm{x}$ year interaction was not significant $(\mathrm{P}>0.05)$, therefore main effects are shown. With the control, seed was established with a disc opener, but $\mathrm{N}$ was broadcast rather than placed in the row. If bars do not share a common letter, the bars were significantly different $(\mathrm{P}<0.05)$. 

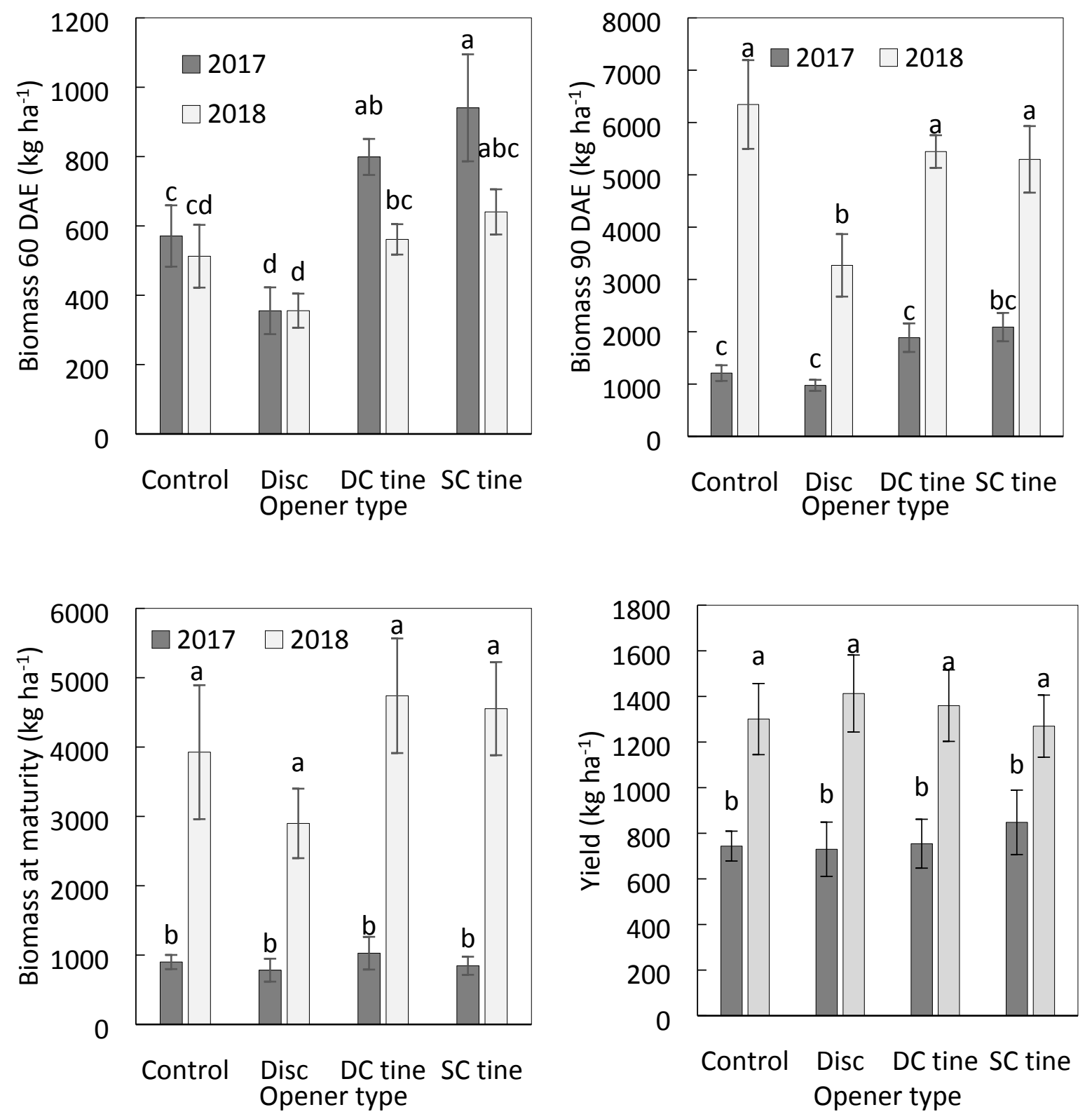

Fig. 5. Aboveground biomass and crop yield of canola planted with a single disc opener, singlechute (SC) and a double-chute (DC) tine opener, with its associated $\mathrm{N}$ placement characteristics. With the control, seed was established with a disc opener, but nitrogen was broadcast rather than placed in the row. If bars do not share a common letter, the bars were significantly different $(\mathrm{P}<0.05)$. 

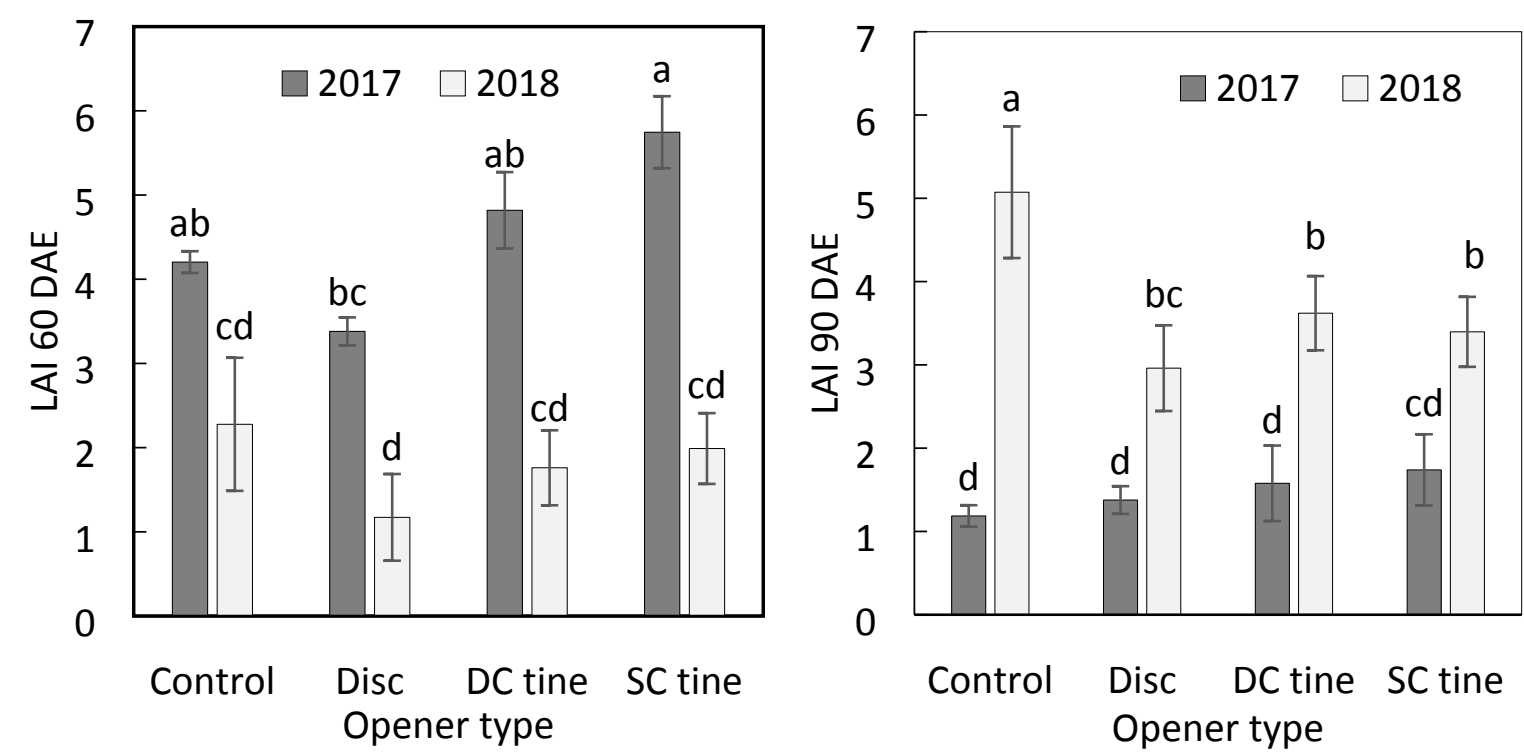

Fig. 6. Leaf area index (LAI) of canola planted with a single disc opener, single-chute (SC) and double-chute (DC) tine opener, with its associated N placement characteristics. With the control, seed was established with a disc opener, but nitrogen was broadcasted rather than placed in the row. If bars do not share a common letter, the bars was significantly different $(\mathrm{P}<0.05)$. 